\title{
HUBUNGAN BURNOUT PERAWAT DENGAN KOMUNIKASI TERAPEUTIK DI RUANG RAWAT INAP RUMAH SAKIT UMUM DAERAH (RSUD) KOTA DEPOK
}

\author{
${ }^{1}$ Nita Ekawati, ${ }^{2}$ Tamara Mika Fahreza \\ 1,2 Program Studi S1 Keperawatan Stikes Widya Dharma Husada Tangerang \\ 1Email: nitaekawati@wdh.ac.id
}

\begin{abstract}
Abstrak
Burnout sebagai keadaan kelelahan fisik, emosional, dan mental yang dihasilkan dari keterlibatan jangka panjang dalam situasi kerja yang menuntut emosional. Kelelahan emosional dapat menyebabkan perasaan depersonalisasi, dimensi kedua dari burnout ini terjadi saat seseorang memiliki sikap yang acuh tak acuh dan dingin, serta menganggap hal tersebut lebih baik dibandingkan jika dirinya merasa kecewa. Seseorang yang mengalami depersonalisasi menganggap orang lain sebagai objek, seperti memandang klien secara negative atau bersikap sinis. Tujuan penelitian ini adalah untuk mengetahui hubungan burnout perawat dengan komunikasi terapeutik di Ruang Rawat Inap Rumah Sakit Umum Daerah (RSUD) Kota Depok. Metode penelitian ini merupakan penelitian kuantitatif yang menggunakan data primer (kuesioner) dan memakai metode cross sectional, menggunakan uji statistik korelasi spearman data yang dikumpulkan sebanyak 40 perawat yang berada di ruang rawat inap (RSUD) Kota Depok. Hasil penelitian menunjukan sebagian besar responden mengalami burnout rendah sebanyak 33 perawat, dan sebanyak 37 perawat melakukan komunikasi terapeutik baik. dari hasil tersebut diperoleh nilai signifikan sebesar 0,902 $(<0,05)$ menunjukan bahwa korelasi tidak signifikan atau hipotesis alternative (ha) ditolak yang berarti tidak ada hubungan antara variabel burnout perawat dengan komunikasi terapeutik. Saran hasil penelitian ini dapat menjadi bahan pertimbangan bagi institusi pendidikan khususnya bagi mahasiswa dalam pengetahuan tentang burnout pada perawat.
\end{abstract}

Kata kunci: Burnout, Perawat, Komunikasi Terapeutik.

\begin{abstract}
Burnout as a state of physical, emotional, and mental fatigue resulted from long-term involvement in the work situation that demands emotional. Emotional fatigue can lead to a depersonalization feeling, the second dimension of this burnout occurs when a person has an indifferent and cold attitude, and considers it to be better than if he or she feels disappointed. A depersonalization person considers someone else an object, like looking at a client negatively or being cynical. The purpose of this research is to know the relationship of a nurse's burnout with therapeutic communication in the inpatient room of the district general hospita (RSUD) Depok City. This method of research is quantitative research using primary data (questionnaires) and using cross sectional method, use statistical test correlation Spearman data collected as much as 40 nurses in the inpatient room (RSUD) Depok City. The results showed that most of the respondents experienced a low burnout of 33 nurses, and as many as 37 nurses performed good therapeutic communication. Of these results obtained a significant value of $0.902(<0.05)$ indicating that the correlation is not significant or the hypothesis alternative (ha) is rejected which means there is no link between the variable Burnout nurse with therapeutic communication. Advice on the results of this research can be a consideration for educational institutions especially for students in the knowledge of burnout on nurses
\end{abstract}

Keywords: Burnout, Nurse, Therapeutic Communication. 


\section{PENDAHULUAN}

Keperawatan adalah salah satu profesi di rumah sakit yang berperan penting dalam upaya menjaga mutu pelayanan kesehatan di rumah sakit. Pada standar tentang evaluasi dan pengendalian mutu dijelaskan bahwa pelayanan keperawatan menjamin adanya asuhan keperawatan yang bermutu tinggi dengan terus-menerus melibatkan diri dalam program pengendalian mutu di rumah sakit. Untuk itu, perawat berkerja secara holistik dengan memberikan perawatan, edukasi, motivasi, bahkan sebagai advokat dan membantu menentukan kebijakan yang berpengaruh terhadap kesehatan baik dirumah sakit dan masyarakat (Potter, Perry, Stockert, \& Hall, 2013).

Berdasarkan pengertian keperawatan, perawat tentu memiliki peran dan tanggung jawab yang besar terhadap beban kerja dan mempengaruhi kondisi fisik dan emosionalnya sendiri. Apabila tugas dan tanggung jawab yang dialami perawat berlebihan hingga berdampak pada kondisi fisik dan emosionalnya, terutama kelemahan emosionalnya sendiri. Apabila tugas dan tanggung jawab yang dialami perawat berlebihan hingga berdampak pada kondisi fisik dan emosionalnya, terutama kelelahan emosional, depersonalisasi, serta penurunan prestasi kerja, pada kondisi tersebut perawat dapat dinyatakan mengalami burnout. Dibandingkan dengan tenaga kesehatan yang lain, perawat memiliki tingkat stress dan burnout yang paling tinggi, hal tersebut karena perawat yang selalu kontak langsung dengan klien, menghabiskan waktu dengan klien, dan secara konstan terpajan ketegangan akan rasa sakit dan kematian. Hal ini didukung dengan penelitian internasional yang menunjukan prevalensi burnout pada perawat berkisar antara 30-80\% (Tay, Ernest, Tan, dan Ng 2014 dalam Claudia, 2017).

Penelitan mengenai burnout pada perawat juga didukung oleh Demerouti et al (2000) dalam Farmer (2014) yang mendeskripsikan profesi perawat sangat rentan terhadap burnout dengan tingkat stress dalam tuntutan kerja yang berat, baik secara emosi dan fisik. Klien yang mendapatkan perawatan dari perawat harus menghadapi kondisi yang sulit untuk mempertahankan hidupnya sehingga sangat bergantung terhadap dukungan fisik dan emosional dari perawat. Selain hal tersebut, shift kerja dan kurangnya penghargaan yang diberikan terhadap perawat, baik dari segi kurang baiknya manajemen kerja, gaji yang dibayarkan, dan lainnya akan meningkatkan potensi burnout dikalangan perawat.

Istilah burnout pertama kali dikemukakan oleh Herbert Freudenberger pada artikel 
"Staff Burnout" yang dimuat Journal of Social Issues tahun 1974 (Schaufeli dan Buunk, 1993 dalam Umar 2013). Istilah burnout dipakai Freudenberger untuk menunjukkan adanya stres dan kelelahan luar biasa yang dialami sukarelawan pada klinik gratis di New York yang bekerja menangani ketergantungan obat.

Perawat yang mengalami burnout dan mempunyai lingkungan yang kurang aman dapat memberikan perawatan yang kurang efisien daripada perawat yang tidak mengalami burnout. Perawat yang mengalami burnout juga beresiko melakukan kesalahan yang berpotensi merugikan pasien. Burnout juga terbukti menjadi penyebab terjadinya peningkatan turnover sehingga membuat cost rumah sakit semakin meningkat (Hoskins, 2013).

Kecenderungan burnout yang dialami perawat dalam bekerja akan sangat mempengaruhi kualitas pelayanan keperawatan yang diberikan kepada pasien, serta dapat menyebabkan efektifitas pekerjaan menurun, hubungan sosial antar rekan kerja menjadi renggang, dan timbul perasaan negative terhadap pasien, pekerjaan, dan tempat kerja perawat. Dengan demikian, gejala yang menunjukan adanya kecenderungan burnout yang dialami oleh perawat perlu mendapatkan perhatian yang cukup serius dari pihak terkait, dalam hal ini adalah manajemen rumah sakit. Banyak hal yang mempengaruhi burnout di rumah sakit, diantaranya ada beberapa faktor yaitu beban kerja yang fluktuatif, shif kerja yang Panjang, kurangnya waktu istirahat, tuntutan pimpinan dan keluarga pasien, serta karakteristik pasien yang mengakibatkan kelelahan, tekanan, dan stress sehingga terjadi burnout pada perawat.

Menurut penelitian pada perawat di Tehran's Milad Hospital, Iran pada tahun 2012, burnout pada 125 perawat dapat diprediksi melalui usia dan jenis kelamin dengan hasil peningkatan dukungan sosial perawat dapat meningkatkan kemampuan mereka untuk bertahan dalam stres kerja dan menurunkan burnout secara efektif (Khalafi, Tangestani, dan Osanloo, 2014). Di Cina, masalah burnout pada perawat juga merupakan isu yang signifikan terbukti dengan hasil penelitian yang menyatakan adanya hubungan antara usia, pengelaman kerja, dan gelar terhadap kelelahan emosi, kepuasan kerja, dan depersonalisasi. Perawat dengan usia ratarata 31-35 tahun memiliki angka kelelahan emosional lebih tinggi dibandingkan dengan usia 21-25 tahun. Selain usia, status pernikahan, jabatan, dan tingkat Pendidikan yang semakin tinggi, juga berpengaruh dalam meningkatkan kelelahan emosional 
pada perawat (Cheng, Meng, dan Jin, 2015).

Burnout juga terjadi pada perawat di Indonesia, salah satunya terdapat dalam penelitian Suharti tahun (2013) didapatkan bahwa dari 110 perawat yang berkerja di Rumah Sakit Metropolitan Medical Center Jakata bagian UGD, Unit Operasi, Unit Rawat Jalan, Unit Rawat Inap, ICU, terdapat 98 orang perawat yang mengalami burnout tingkat sedang.

Menurut Muhith dan Siyoto (2018) komunikasi yang terapeutik adalah ketika dalam berkomunikasi dengan klien, perawat mendapatkan gambaran yang jelas dan alami tentang kondisi klien yang sedang dirawat mengenai tanda dan gejala yang ditampakan serta keluhan yang dirasakan. Komunikasi terapeutik merupakan hubungan perawat dan klien yang dirancang untuk memfasilitasi tujuan terapi dalam pencapaian tingkatan kesembuhan yang optimal dan efektif. Harapannya dengan adanya kegiatan komunikasi yang terapeutik, lama hari rawat klien menjadi lebih pendek dan dipersingkat. Terjadinya komunikasi terapeutik adalah apabila didahului hubungan saling percaya antara perawat dan klien.

Perawat yang memiliki keterampilan berkomunikasi secara terapeutik tidak saja akan mudah menjalin hubungan rasa percaya dengan klien, mencegah terjadinya masalah legal, memberikan kepuasan profesioneldalam pelayanan keperawatan dan meningkatkan citra profesi keperawatan serta citra rumah sakiy, tetapi yang paling penting adalah mengamalkan ilmunya untuk memberikan pertolongan terhadap sasama manusia (Astuti Ardi Putri, 2015).

Tidak dapat dipungkiri, bahwa kepuasan pasien tergantung pada kualitas pelayanan, maka pelaksanaan komunikasi terapeutik oleh perawat merupakan salah satu indikasi untuk meningkatkan kualitas pelayanan yang dirasakan oleh pasien dan keluarganya. Pelaksanaan komunikasi terapeutik yang lebih baik di suatu Rumah Sakit, akan menyebabkan pasien dan keluarganya merasa lebih puas, kembali memilih Rumah Sakit tersebut bila memerlukan dan menceritakan kepuasannya kepada orang lain. Dimana efek menceritakan kepuasan atau ketidakpuasan suatu produk atau pelayanan jasa dapat mempengaruhi pemilihan produk jasa dari orang lain yang mendengar. Hal ini juga didasari oleh pentingnya informasi dari mulut ke mulut (word of mouth) dalam bauran promosi industri jasa rumah sakit (Lupiyoadi \& Hamdani 2009 dalam Novi dan Zahroh, 2017). 
Data yang tercatat di World Health Organization (WHO) tahun 2011 melaporkan bahwa jumlah perawat ada sekitar 19,3 juta perawat. Berdasarkan data rekapitulasi Badan Pengembangan dan Pemberdayaan Sumber Daya Manusia Kesehatan (BPPSDMK) tahun 2016 ada 296,876 orang perawat di Indonesia yang tercatat. Sedangkan jumlah tenaga keperawatan pada tahun 2016 yang ada di jawa barat adalah 33,527 orang perawat. Data tersebut terkumpul dari berbagai fasilitas pelayanan kesehatan di antaranya puskesmas, rumah sakit pemerintah, dan beberapa rumah sakit swasta yang tercatat di Badan Pengembangan dan Pemberdayaan Sumber Daya Manusia Kesehatan (BPPSDMK, 2016). Data yang tercatat oleh Dinas Kesehatan Kota Depok pada tahun 2017 tenaga keperawatan yang ada di kota depok adalah 2.695 orang perawat. Dan berdasarkan data yang didapat jumlah perawat yang ada di Rumah Sakit Umum Daerah (RSUD) Kota Depok adalah 152 perawat.

Setelah peneliti melakukan studi pendahuluan dengan cara observasi dan wawancara di Rumah Sakit Umum Daerah (RSUD) Kota Depok pada ruang rawat inap dan Instalasi Gawat Darurat (IGD), peneliti menemukan sekitar 10 orang perawat mengalami burnout, 3 orang diantaranya perawat tersebut tidak melakukan komunikasi terapeutik dengan baik.

Pada saat peneliti melakukan obeservasi di Rumah Sakit Umum Daerah (RSUD) Kota Depok, peniliti juga menemukan kurangnya komunikasi yang dilakukan perawat kepada klien dan keluarga akibat kegiatan langsung keperawatan dan kegiatan administratif, serta rekam medik yang menyita waktu. Oleh karena itu peneliti memilih melakukan tempat penelitian di Rumah Sakit Umum Daerah (RSUD) Kota Depok mengingat rumah sakit ini merupakan Rumah Sakit Umum Daerah (RSUD) satu-satunya di kota depok.

\section{METODE}

Desain penelitian ini menggunakan metode kuantitatif dan menggunakan desain analitik dengan pendekatan cross sectional yaitu penelitian dengan cara pendekatan, observasi, atau pengumpulan data yang dilakukan pada subjek saat pemeriksaan, metode ini mengunakan kuisoner (pertanyaan). Penelitian ini dilakukan di Rumah Sakit Umum Daerah (RSUD) Kota Depok dengan melibatkan 40 perawat yang bererja dibagian ruang rawat inap dengan metode total sampling. Penelitian ini mengguankan analisis univariat mengacu pada instrumen data demografi meliputi usia, jenis kelamin, pengalaman kerja, tingkat Pendidikan, burnout dan 
komunikasi terapeutik. Analisis bivariat ini mengangkat variabel confounding yaitu usia, jenis kelamin, pengalaman kerja, tingkat Pendidikan. Pada analisis bivariat untuk mengetahui Usia dengan burnout perawat, Jenis kelamin dengan burnout perawat, Pengalaman kerja dengan burnout perawat, Tingkat pendidikan dengan burnout perawat, dan Burnout perawat dengan komunikasi terapeutik.

\section{HASIL DAN PEMBAHASAN ANALISIS UNIVARIAT}

Gambaran karakteristik responden menurut usia di ruang rawat inap Rumah Sakit Umum Daerah (RSUD) Kota Depok yang sebagian besar responden memiliki usia 2635 tahun 18 responden (42\%), sedangkan nilai terendah memiliki usia 17-25 tahun sebanyak 9 responden (22\%), karakteristik responden menurut jenis kelamin di ruang rawat inap Rumah Sakit Umum Daerah (RSUD) Kota Depok yang sebagian besar responden berjenis kelamin perempuan yaitu sebanyak 38 responden $(95 \%)$ dan berjenis kelamin laki-laki sebanyak 2 (5\%), karakteristik responden menurut tingkat pendidikan di ruang rawat inap Rumah Sakit Umum Daerah (RSUD) Kota Depok yang sebagian besar responden memiliki tingkat pendidikan D3 yaitu sebanyak 23 responden $(57,5 \%)$, kemudian responden yang memiliki tingkat pendidikan S1/Ners sebanyak 17 (42,5\%), karakteristik responden menurut pengalaman kerja di ruang rawat inap Rumah Sakit Umum Daerah (RSUD) Kota Depok yang sebagian besar responden memiliki pengalaman kerja 6-10 tahun sebanyak 21 responden $(52,5 \%)$, kemudian responden memiliki pengalaman $>11$ tahun sebanyak 3 responden (7,5\%), gambaran burnout perawat di Ruang Rawat Inap Rumah Sakit Umum Daerah (RSUD) Kota Depok menunjukan bahwa sebanyak 7 responden $(17,5 \%)$ memiliki tingkat bunout sedang, sedangkan sebanyak 33 responden $(82,5 \%)$ memiliki tingkat burnout rendah, karakteristik komunikasi terapeutik di Ruang Rawat Inap Rumah Sakit Umum Daerah (RSUD) Kota Depok menunjukan bahwa sebanyak 3 responden $(7,5 \%)$ memiliki kemampuan komunikasi terapeutik kurang, sedangkan sebanyak 37 responden $(92,5 \%)$ memiliki kemampuan komunikasi terapeutik baik.

\section{ANALISIS BIVARIAT}

Tabel 1. Hubungan antara usia dengan burnout perawat di Ruang Rawat Inap Rumah Sakit Umum Daerah (RSUD) Kota Depok.

\begin{tabular}{|c|c|c|c|c|c|c|c|}
\hline \multirow{3}{*}{ Usia } & \multicolumn{4}{|c|}{ Burnout } & & & \multirow{3}{*}{$\begin{array}{c}\mathrm{P} \\
\text { value }\end{array}$} \\
\hline & \multicolumn{2}{|c|}{ Rendah } & \multicolumn{2}{|c|}{ Sedang } & \multicolumn{2}{|c|}{ Total } & \\
\hline & $\mathrm{n}$ & $\%$ & $\mathrm{n}$ & $\%$ & $\mathrm{n}$ & $\%$ & \\
\hline $17-25$ & 7 & 17.5 & 2 & 5.0 & 9 & 22.5 & \\
\hline \multicolumn{8}{|l|}{ Tahun } \\
\hline $26-35$ & 12 & 30.0 & 4 & 10.0 & 16 & 40.0 & \multirow{4}{*}{0,250} \\
\hline Tahun & & & & & & & \\
\hline $36-45$ & 14 & 35.0 & 1 & 2.5 & 15 & 37.5 & \\
\hline Tahun & & & & & & & \\
\hline Total & 33 & 82.5 & 7 & 17.5 & 40 & 100.0 & \\
\hline
\end{tabular}


Hubungan antara usia dengan burnout perawat di Ruang Rawat Inap Rumah Sakit Umum Daerah (RSUD) Kota Depok menunjukkan diketahui nilai signifikansi atau Sig. (2-tailed) sebesar 0,250, karena nilai Sig. (2-tailed) $0,250>0,05$ menunjukkan bahwa korelasi tidak signifikan atau hipotesis alternative (ha) ditolak yang berarti tidak ada hubungan yang signifikan (bermakna) antara usia dengan burnout perawat. lebih teguh sehingga memiliki pandangan yang lebih realistis.

Tabel 2. Hubungan antara jenis kelamin dengan burnout perawat di Ruang Rawat Inap Rumah Sakit Umum Daerah (RSUD) Kota Depok.

\begin{tabular}{|c|c|c|c|c|c|c|c|}
\hline \multirow{3}{*}{$\begin{array}{c}\text { Jenis } \\
\text { Kelamin }\end{array}$} & \multicolumn{4}{|c|}{ Burnout } & \multirow{2}{*}{\multicolumn{2}{|c|}{ Total }} & \multirow{2}{*}{$\begin{array}{c}\mathrm{P} \\
\text { valu } \\
\mathrm{e}\end{array}$} \\
\hline & \multicolumn{2}{|c|}{ Rendah } & \multicolumn{2}{|c|}{ Sedang } & & & \\
\hline & $\mathrm{n}$ & $\%$ & $\mathrm{n}$ & $\%$ & $\mathrm{n}$ & $\%$ & \\
\hline Laki-Laki & 1 & 2.5 & 1 & 2.5 & 2 & 5.0 & \\
\hline Perempuan & $\begin{array}{l}3 \\
2\end{array}$ & 80.0 & 6 & 15.0 & 38 & 95.0 & $\begin{array}{c}0.22 \\
5\end{array}$ \\
\hline Total & $\begin{array}{l}3 \\
3\end{array}$ & 82.5 & 7 & 17.5 & 40 & 100.0 & \\
\hline
\end{tabular}

Penelitian ini tidak sejalan dengan penelitian yang dilakukan sebelumnya oleh Neli Suharti (2013) dengan judul burnout dengan kinerja perawat di rumah sakit metropolitan medical center Jakarta dengan nilai signifikan yaitu sebesar 0,035 menunjukan terdapat hubungan usia dengan tingkaan burnout perawat di Rumah Sakit Metropolitan Medical Center Jakarta.

Perawat merupakan profesi yang penuh dengan stress karena setiap hari berhadapan dengan penderita yang mempunyai karakter yang berbeda-beda, semakin cukup usia tingkat berfikir juga lebih baik (Nursalam, 2014). Para pekerja pemberi pelayanan di usia muda dipenuhi dengan harapan tidak realistisk, jika dibandingkan dengan mereka yang berusia lebih tua. Seiring dengan pertambahan usia pada umumnya individu menjadi lebih matang, lebih stabil,

Hubungan antara jenis kelamin dengan burnout perawat di Ruang Rawat Inap Rumah Sakit Umum Daerah (RSUD) Kota Depok menunjukkan nilai signifikansi atau Sig. (2-tailed) sebesar 0,225, karena nilai Sig. (2-tailed) 0,225>0,05 menunjukkan bahwa korelasi tidak signifikan atau hipotesis alternative (ha) ditolak yang berarti tidak ada hubungan antara jenis kelamin dengan burnout perawat di Ruang Rawat Inap Rumah Sakit Umum Daerah (RSUD) Kota Depok.

Penelitian ini tidak sejalan dengan penelitian yang dilakukan sebelumnya oleh Ika Kasmita Sari (2015) dengan faktorfaktor yang berhubungan dengan burnout perawat di RSUD Haji Makassar dengan nilai signifikan yaitu sebesar 0,000 menunjukan terdapat hubungan antara jenis 
kelamin dengan tingkaan burnout perawat di RSUD Haji Makassar.

Pada dasarnya burnout dapat terjadi pada semua orang, baik itu laki-laki dan perempuan.Hal ini terjadi karena setiap manusia tentu mengalami tekanan yang diperoleh dalam kehidupan khususnya dalam menjalani pekerjaan (Sitohang dalam Eliyana, 2015).

Menurut maslach dalam Sulis (2011) bahwa wanita yang mengalami burnout cenderung mengalami kelelahan emosional dan laki-laki yang mengalami burnout cenderung mengalami depersonalisasi.Artina perawat laki-laki yang mengalami depersonalisasi cenderung menjaga jarak dengan penerima pasien, cenderung tidak peduli terhadap lingkungan serta orang-orang disekitarnya dan mengurangi kontak dengan pasien.

Tabel 3. Hubungan antara tingkat pendidikan dengan burnout perawat di Ruang Rawat Inap Rumah Sakit Umum Daerah (RSUD) Kota Depok.

\begin{tabular}{|c|c|c|c|c|c|c|c|}
\hline \multicolumn{7}{|c|}{ Burnout } & \multirow{3}{*}{$\begin{array}{c}\mathrm{P} \\
\text { valu } \\
\mathrm{e} \\
\end{array}$} \\
\hline \multirow{2}{*}{$\begin{array}{l}\text { Tingkat } \\
\text { Pendidik } \\
\text { an }\end{array}$} & \multicolumn{2}{|c|}{ Rendah } & \multicolumn{2}{|c|}{ Sedang } & \multicolumn{2}{|c|}{ Total } & \\
\hline & $\mathrm{N}$ & $\%$ & $\mathrm{n}$ & $\%$ & $\mathrm{n}$ & $\%$ & \\
\hline \multirow[t]{2}{*}{ D3 } & 1 & 45. & 5 & 12. & 2 & 57.5 & \multirow{6}{*}{$\begin{array}{c}0.42 \\
5\end{array}$} \\
\hline & 8 & 0 & & 0 & 3 & & \\
\hline \multirow[t]{2}{*}{ S1/Ners } & 1 & 37. & 2 & 5.0 & 1 & 42.5 & \\
\hline & 5 & 5 & & & 7 & & \\
\hline \multirow[t]{2}{*}{ Total } & 33 & 82.5 & 7 & 17.5 & 4 & 100. & \\
\hline & & & & & 0 & 0 & \\
\hline
\end{tabular}

Hubungan antara tingkat pendidikan dengan burnout perawat di Ruang Rawat Inap Rumah Sakit Umum Daerah (RSUD) Kota Depok menunjukkan nilai signifikansi atau Sig. (2-tailed) sebesar 0,425, karena nilai Sig. (2-tailed) $0,425>0,05$ menunjukan bahwa korelasi tidak signifikan atau hipotesis alternative (ha) ditolak yang berarti tidak ada hubungan antara tingkat pendidikan dengan burnout perawat di Ruang Rawat Inap Rumah Sakit Umum Daerah (RSUD) Kota Depok.

Penelitian ini sejalan dengan penelitian yang dilakukan sebelumnya oleh Neli Suharti (2013) dengan judul burnout dengan kinerja perawat di rumah sakit metropolitan medical center Jakarta dengan nilai signifikan yaitu sebesar 0,600 menunjukan tidak terdapat hubungan antara tingkat pendidikan dengan tingkaan burnout perawat di Rumah Sakit Metropolitan Medical Center Jakarta.

Tabel 4. Hubungan antara pengalaman kerja dengan burnout perawat di Ruang Rawat Inap Rumah Sakit Umum Daerah (RSUD) Kota Depok.

\begin{tabular}{|c|c|c|c|c|c|c|c|}
\hline \multirow{3}{*}{$\begin{array}{c}\text { Pengalaman } \\
\text { Kerja }\end{array}$} & \multicolumn{4}{|c|}{ Burnout } & & & \multirow{2}{*}{$\begin{array}{c}\mathrm{P} \\
\text { value }\end{array}$} \\
\hline & \multicolumn{2}{|c|}{ Rendah } & \multicolumn{2}{|c|}{ Sedang } & \multicolumn{2}{|c|}{ Total } & \\
\hline & $\mathrm{N}$ & $\%$ & $\mathrm{n}$ & $\%$ & $\mathrm{n}$ & $\%$ & \\
\hline 1-5 Tahun & 12 & 30. & 4 & $\begin{array}{c}10 . \\
0\end{array}$ & 16 & 40.0 & 0.516 \\
\hline 6-10 Tahun & 19 & $\begin{array}{c}47 . \\
5\end{array}$ & 2 & 5.0 & 21 & 52.5 & \\
\hline$>11$ Tahun & 2 & 5.0 & 1 & 2.5 & 3 & 7.5 & \\
\hline Total & 33 & 82.5 & 7 & 17.5 & 40 & $\begin{array}{c}100 . \\
0\end{array}$ & \\
\hline
\end{tabular}


Hubungan antara pengalaman kerja dengan burnout perawat di Ruang Rawat Inap Rumah Sakit Umum Daerah (RSUD) Kota Depok menunjukkan nilai signifikansi atau Sig. (2-tailed) sebesar 0,225, karena nilai Sig. (2-tailed) 0,225 > 0,05 menunjukkan bahwa korelasi tidak signifikan atau hipotesis alternative (ha) ditolak yang berarti tidak ada hubungan antara pengalaman kerja dengan burnout perawat di Ruang Rawat Inap Rumah Sakit Umum Daerah (RSUD) Kota Depok.

Penelitian ini sejalan dengan penelitian yang dilakukan sebelumnya oleh Sari (2015) dengan hasil analisis antara masa kerja dengan burnout syndrome dengan nilai signifikan yaitu sebesar 0,064 meunjukan tidak terdapat hubungan antara masa kerja dengan burnout syndrome.

Hal ini tidak sejalan dengan penelitian Ika Kasmita Sari (2015) dengan faktor-faktor yang berhubungan dengan burnout perawat di RSUD Haji Makassar dengan nilai signifikan yaitu sebesar 0,001 menunjukan terdapat hubungan antara masa kerja dengan tingkaan burnout perawat di RSUD Haji Makassar.

Farber menyatakan bahwa semakin banyak pengalaman kerja semakin rendah tingkat burnout yang dialami seseorang, sebaliknya minimnya pengalaman kerja maka semakin tinggi burnout yang dialami (Triwijayanti,
2016).Walaupun dengan masa kerja yang lama seorang perawat mendapatkan pengalaman kerja yang banyak, namun pola pekerjaan perawat yang monoton dan bersifat human service justru menimbulkan kelelahan fisisk, emosi dan psikoligi yang mengarah pada burnout syndrome (Pangastiti, 2011).

Tabel 5. Hubungan antara burnout perawat dengan komunikasi terapeutik di Ruang Rawat Inap Rumah Sakit Umum Daerah (RSUD) Kota Depok.

\begin{tabular}{|c|c|c|c|c|c|c|c|}
\hline \multirow{3}{*}{ Burnout } & \multicolumn{4}{|c|}{ Komunikasi Terapeutik } & & & \multirow{3}{*}{$\begin{array}{c}\mathrm{P} \\
\text { value }\end{array}$} \\
\hline & \multicolumn{2}{|c|}{$\begin{array}{c}\text { Kurang } \\
\text { Baik }\end{array}$} & \multicolumn{2}{|c|}{ Baik } & \multicolumn{2}{|c|}{ Total } & \\
\hline & $\mathrm{n}$ & $\%$ & $\mathrm{n}$ & $\%$ & $\mathrm{~N}$ & $\%$ & \\
\hline Rendah & 3 & 7.5 & 30 & 75.0 & 33 & 82.5 & \multirow{3}{*}{0.420} \\
\hline Sedang & 0 & 0.0 & 7 & 17.5 & 7 & 17.5 & \\
\hline Total & 3 & 7.5 & 37 & 92.5 & 40 & 100.0 & \\
\hline
\end{tabular}

Hubungan Burnout perawat dengan komunikasi terapeutik menunjukkan bahwa nilai signifikansi atau Sig. (2-tailed) sebesar 0,902, karena nilai Sig. (2-tailed) 0,902 > 0,05 menunjukkan bahwa korelasi tidak signifikan atau hipotesis alternative (ha) ditolak yang berarti tidak ada hubungan antara variabel burnout perawat dengan komunikasi terapeutik.

Penelitian ini tidak sejalan dengan penelitian yang dilakukan sebelumnya oleh Azra Ahmadi, dkk (2013) dengan judul hubungan burnout dan keterampilan komunikasi pada perawat dengan nilai sinifikan yaitu sebesar 0,001 menunjukan 
terdapat hubungan burnout dan keterampilan komunikasi pada perawat. Greenberg (2012) dalam Claudia (2017) menjelaskan faktor lain yang memngakibatkan burnout yaitu kurangnya kontrol di tempat kerja ketidak cukupan reward, perpecahan komunikasi kerja, kurangnya kepercayaan, keterbukaan, tidak terdapat kejujuran, dan menghargai pekerjaan.

Secara tidak langsung bisa dikatakan bahwa burnout bukanlah faktor utama demi terciptanya komunikasi terapeutik, karena dengan burnout rendah pun komunikasi terapeutik tetap baik.

\section{KESIMPULAN}

1. Gambaran karakteristik responden menurut usia di ruang rawat inap Rumah Sakit Umum Daerah (RSUD) Kota Depok yang sebagian besar responden memiliki usia 26-35 tahun 18 responden $(42 \%)$, sedangkan nilai terendah memiliki usia 17-25 tahun sebanyak 9 responden $(22 \%)$.

2. Gambaran karakteristik responden menurut jenis kelamin di ruang rawat inap Rumah Sakit Umum Daerah (RSUD) Kota Depok yang sebagian besar responden berjenis kelamin perempuan yaitu sebanyak 38 responden $(95 \%)$ dan berjenis kelamin laki-laki sebanyak $2(5 \%)$.

3. Gambaran karakteristik responden menurut tingkat pendidikan di ruang rawat inap Rumah Sakit Umum Daerah (RSUD) Kota Depok yang sebagian besar responden memiliki tingkat pendidikan D3 yaitu sebanyak 23 responden $(57,5 \%)$, kemudian responden yang memiliki tingkat pendidikan S1/Ners sebanyak 17 $(42,5 \%)$.

4. Gambaran karakteristik responden menurut pengalaman kerja di ruang rawat inap Rumah Sakit Umum Daerah (RSUD) Kota Depok yang sebagian besar responden memiliki pengalaman kerja 6-10 tahun sebanyak 21 responden $(52,5 \%)$, kemudian responden memiliki pengalaman $>11$ tahun sebanyak 3 responden $(7,5 \%)$.

5. Gambaran burnout perawat di Ruang Rawat Inap Rumah Sakit Umum Daerah (RSUD) Kota Depok menunjukan bahwa sebanyak 7 responden $(17,5 \%)$ memiliki tingkat bunout sedang, sedangkan sebanyak 33 responden $(82,5 \%)$ memiliki tingkat burnout rendah.

6. Karakteristik komunikasi terapeutik di Ruang Rawat Inap Rumah Sakit Umum Daerah (RSUD) Kota Depok menunjukan bahwa sebanyak 3 responden $\quad(7,5 \%) \quad$ memiliki 
kemampuan komunikasi terapeutik kurang, sedangkan sebanyak 37 responden $(92,5 \%) \quad$ memiliki kemampuan komunikasi terapeutik baik.

7. Tidak ada hubungan antara usia dengan burnout perawat di Ruang Rawat Inap Rumah Sakit Umum Daerah (RSUD) Kota Depok.

8. Tidak ada hubungan antara jenis kelamin dengan burnout perawat di Ruang Rawat Inap Rumah Sakit Umum Daerah (RSUD) Kota Depok.

9. Tidak ada hubungan antara tingkat pendidikan dengan burnout perawat di Ruang Rawat Inap Rumah Sakit Umum Daerah (RSUD) Kota Depok.

10. Tidak ada hubungan antara pengalaman kerja dengan burnout perawat di Ruang Rawat Inap Rumah Sakit Umum Daerah (RSUD) Kota Depok.

11. Tidak ada hubungan antara burnout perawat dengan komunikasi terapeutik di Ruang Rawat Inap Rumah Sakit Umum Daerah (RSUD) Kota Depok.

\section{DAFTAR PUSTAKA}

Afnuhazi, R. 2015. Komunikasi Terapeutik Dalam Keperawatan Jiwa. Yogyakarta : Gosyen Publishing.
Ahmadi, A. 2013. The Relationship Of Occupational Burnout And Communication Skills In Nurses.

Asmadi. 2008. Konsep Dasar Keperawatan. Jakarta : EGC

Budiyono. 2016. Konsep Dasar Keperawatan. Jakarta Selatan : Kementrin Kesehatan Republik Indonesia

Cheng, F., Meng, A., \& Jin, T. 2015. Correlation Between Burnout And Professional Value In Chinese Oncology Nurses. A Questionnaire Survey: Internasional Jurnal Of Nursing Sciences

Christina, E. 2012. Hubungan Motivasi Dengan Penerapan Komunikasi Terapeutik Oleh Perawat Pada Pasien Di Ruang Rawat Inap Rumah Sakit Jiwa Dr.Seoharto Heerdjan Jakarta (Skripsi)

Eliyana. 2015. Faktor-Faktor Yang Brhubungan Dengan Burnout Perawat Pelaksana Di Ruang Rawat Inap RSJ Provinsi Kalimantan Barat

Farmer, S. 2014. The Relationship of Emotional Intelligence to Burnout And Job Satisfaction Among Nurses In Early Nursing Practice

Fradelos. et. al. 2014. Assessment of Burnout And Quality of Live in Nursing Professionals: The Contribution of Perceived Social Support

Greenberg, J. S. 2011. Comprehensice Stress Management. New York: McGraw-Hill

Hoskins, K. N. 2013. The Possible Role Of Burnout In Nursing Errors. Orlando

Sari, I. K. 2015. Faktor-Faktor Yang Berhubungan Dengan Burnout Perawat Di RSUD Haji Makasar. (Skripsi) 
Sari. 2015. Hubungan Beban Kerja. Faktor Demografi, Locus Control Dan Harga Diri Terhadap Burnout Syndrome Pada Perawat Pelaksana IRD Rsup Sanglah.

Jaya, K. 2015. Keperawatan Jiwa. Tangerang Selatan: BINARUPA AKSARA Publisher

Khalafi, T. Y \& Osanloo. 2014. Relationship Between Job Stress and Social Support and Burnout in Nurses. Jurnal Of Novel Applied Sciences

Lee, Kuo, Chien \& Wang. 2015. A MetaAanalysis of the Effects of Coping Strategsie on Reducing Nurse Burnout. Applied Nursing Research Francis e-Library

Mariyanti, S. 2011. Burnout Pada Perawat Yang Bertugas Di Ruang Rawat Inap Dan Rawat Jalan RSAB Harapan Kita. Jakarta : Jurnal Psikologi Universitas Esa Unggul

Miller, D. 2012. Dying ti Care?: Work, Stress and Burnout in HIV/AIDS. London: Taylor

Misi, S. 2016. Komunikasi Terapeutik Perawat Berhubungan Dengan Kepuasan Pasien.

Mizmir. 2011. Hubungan burnout dengan kepuasan kerja pustakawan dipusat jasa perpustakaan nasional RI. (Skripsi)

Mochtar. Dkk. 2013. Faktor Yang Berhubungan Dengan Stres Kerja Pada Pedagang Tradisional Pasar Daya Kota Makasar.

Moria, Englin. Dkk. 2018. Burnout Syndrome Pada Perawat Di Ruangan Rawat Inap Rumah Sakit Santa Elisabeth Medan
Munith, A \& Siyoto S. 2018. Aplikasi Komunikasi Terapeutik Nursing \& Health. Yogyakarta : Penerbit ANDI

Notoatmodjo, S. 2010. Metodologi Penelitian Kesehatan. Jakarta : RINEKA CIPTA

Notoatmodjo, S. 2012. Metodologi Penelitian Kesehatan. Jakarta : RINEKA CIPTA

Nugroho, M. 2012. Studi Deskriptif Burnout Dan Coping Stress Pada Perawat Di Ruang Rawat Inap Rumah Sakit Jiwa Menur Surabaya

Nursalam. 2014. Konsep dan penerapan metodelogi peneitian ilmu keperawatan. Jakarta : Salemba Medika.

Pangastiti, N. K. 2011. Analisis Pengaruh Dukungan Sosial Keluarga Terhadap Burnout Pada Perawat Kesehatan Di Rumah Sakit Jiwa. (Skripsi)

Potter, P. A., Perry, Stockert, \& Hall, A. 2013. Fundamentals of Nursing (8 ed.). Missouri : Elsevier Mosby

Priyoto. 2015. Komunikasi \& Sikap Empati Dalam Keperawatan. Yogyakarta : Graha Ilmu

Putri, A. . 2016. Strategi Budaya Carakter Caring of Nursing. Bogor : IN MEDIA

Ramansyah, D. F. 2017. Hubungan Stress Kerja Dengan Kinerja Perawat Pada Saat Shift Malam Di Instalasi Rawat Inap Rumah Sakit Umum Ksbupsten Tangerang. (Skripsi)

Saifudin. 2011. Metode Penelitian. Yogyakarta : Pustaka Pelajar 
Suermi, T. 2012. Analisa Faktor-Faktor Yang Berhubungan Dengan Tingkat Stress Perawat ICU Di RSU Jawa Tengah (Tesis)

Sugiyono. 2016. Metode penelitian kuantitatif kualitatif dan $R \& D$. Bandung : PT Alfabet

Sugiyono. 2017. Metode penelitian kuantitatif kualitatif dan $R \& D$. Bandung : ALFABETA

Suharti, N. 2013. Hubungan Burnout Dengan Kinerja Perawat Di Rumah Sakit Metropolitan Medical Center Jakarta. (Skripsi)

Sujarweni, Wiratna. 2014. Metodologi Penelitian : Lengkap Praktis, Dan Mudah Dipahami. Yogyakarta : PT Pustaka Baru

Talenta, Claudia. 2017. Hubungan Tingkat Burnout Dengan Perilaku Caring Perawat Terhadap Pasien Di Rumah Sakit Kanker Dharmais. (Skripsi)

Tay, Earnest, Tan, \& Ng. 2014. Prevalence of Burout Among Nurses in a Community Hospital in Singapore: A Cross-Sectional Study. Proceedings Of Singapore Healthcare

Tri, Ezra. 2010. Hubungan Kebisingan Dan Masa Kerja Terhadap Terjadinya Stres Kerja Pada Pekerja Di Bagian Tenun "Agung Saputra Tex" Piyungan Bantul Yogyakarta.

Triwijayanti, Renny. 2016. Hubungan Locus Of Control Dengan Burnout Perawat Di Ruang Rawat Ianap Rumah Sakit Muhammadiyah Palembang.

Umar. Bie Novirenallia. 2013. Analisis Kejadia Burnout Syndrome Pada Perawat Di Unit Rawat Inap Dan
Unit Rawat Jalan Rumah Sakit " $X$ " Bandar Lampung

Wahyuni, D. 2015. Hubungan Antara Efikasi Diri Dengan Burnout Pada Perawat RSUD Arofin Achmad Pekanbaru. (Skripsi)

Zahroh, N. 2017. Perbedaan Komunikasi Terapeutik Perawat Di Ruang Rawat Inap RS Pemerintah Dan RS Swasta 